\title{
Türkiye Merkezli Hakemli Turizm Dergileri Üzerine Bir İnceleme
}

\author{
A Review of Academic Tourism Journals in Turkey
}

\author{
Zaid ALRAWADIEH*, Derya DEMIRDELEN ALRAWADIEH** \\ * (Sorumlu Yazar) Doç. Dr., İstanbul Üniversitesi-Cerrahpaşa, Sosyal Bilimler Meslek Yüksekokulu, Otel, Lokanta ve ỉkram Hizmetleri Bölümü, 34265 , İstanbul. \\ E-posta: zaid.alrawadieh@istanbul.edu.tr \\ ORCID: 0000-0001-8355-9958 \\ ** Dr. Öğr. Üyesi, İstanbul Ayvansaray Üniversitesi, Plato Meslek Yüksekokulu, Otel, Lokanta ve İkram Hizmetleri Bölümü, 34020, İstanbul. \\ E-posta: deryademirdelen@ayvansaray.edu.tr \\ ORCID: 0000-0002-7554-2256
}

MAKALE BILGILERI

Makale işlem bilgileri:

Gönderilme tarihi:31 Aralık 2020

Düzeltme: 18 Şubat 2021

Düzeltme: 17 Mart 2021

Kabul: 18 Mart 2021

Anahtar sözcükler: Turizm dergileri, Bilimsel dergiler, Dergi editörlüğ̈̈, Araştırma kalitesi, Yayın etiğ i, Akademik önderlik.

\section{ARTICLE INFO}

Article history:

Submitted: 31 December 2020

Resubmitted: 18 February 2021

Resubmitted: 17 March 2021

Accepted: 18 March 2021

Key words: Tourism journals, Scientific journals, Journal editorship, Research quality, Publication ethics, Academic leadership.

\section{ÖZ}

Hakemli bilimsel turizm dergilerinin mevcut durumunu değerlendirmek, bilimsel çıktıların güvenilirliği ve bütünlüğünü sağlamak için oldukça önemli olmasına rağmen, Türkiye merkezli hakemli turizm dergileri ile ilgili sistematik ve kapsamlı bir incelemeye rastlanmamaktadır. Bu araştırmada, Türkiye merkezli turizm ve otelcilik dergileri üzerine betimleme yöntemiyle bir inceleme yapılmıştır. Bulgulara göre; 2020 yılının sonu itibariyle, mevcut olan $\mathbf{4 3}$ derginin üçte ikisinin son dört yılda ortaya çıktığı, bu dergilerden ücret talep edenlerin bir sayıda yayımladığı ortalama makale sayısının, ücretli olmayan dergilerde yayımlanan ortalama makale sayısından dört kat fazla olduğu, mevcut dergilerin üç adetinin ise hâlihazırda şaibeli/yağmacı dergilerin listesinde yer aldığı ortaya çıkmıştır. Dergilerin baş editörlerinin akademik profillerine bakıldığında ise; söz konusu editörlerin büyük çoğunluğunun turizm alanında en saygın ilk 10 dergide hic yayını olmadığı; üçte birinin ise Web of Science ve Scopus indeksli dergilerde hiç yayını olmadığı ortaya çıkmıştır. Ayrıca, bu editörlerin önemli bir kısmının şaibeli/yağmacı dergilerde en az bir yayını olduğu ortaya çıkmıştır.

\begin{abstract}
Exploring the state-of-art of tourism journals is crucial to ensure the reliability and integrity of research outcomes. Interestingly, however, no study has been conducted to assess, in a systematic and comprehensive way, the academic tourism journals in Turkey. Drawing on a descriptive approach, the findings suggest that by the end of 2020, there were 43 tourism journals of which two-thirds have appeared over the last four years with three being possibly predatory. The average number of articles published in "author pays" journals is four times the average number of articles published in non-paid journals. Concerning the editors, the findings reveal that the majority of them have no published articles in the top 10 tourism and hospitality journals while one-third of them have no articles published in Web of Science- and Scopus- indexed journals. Surprisingly, however, a good portion of those editors have at least one article published in questionable/predatory journals.
\end{abstract}

\section{GiRiş}

Bilimsel iletişimin en önemli araçlarından biri olan dergilerde yayınlanan çalışmaların, alandaki teorik gelişimi sağlamasının yanı sıra; toplumun refahını etkileyecek uygulamaların ve politikaların ortaya çıkmasında da önemli rol

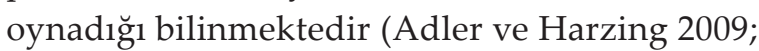
Kozak 2020a). Dolayısıyla hakemli bilimsel dergilerin gelişimini ve şu anki durumunu değerlen- dirmek, bilimsel çıktıların güvenilirliği ve bütünlüğünü sağlamak için önem arz etmektedir. Günümüzde bilimsel çıktıların yayılması için çeşitli ortamlar kullanılsa da; akademik dergilerin, kaliteli araştırmaların yayımlanması için kullanılan en etkin bilimsel iletişim aracı olarak devam edeceği belirtilmektedir (McKercher 2020).

Batı ülkelerinde 20. yüzyılın başlarında ortaya çıkan ve İkinci Dünya Savaşı'ndan itibaren aka- 
demik sahada baş göstermeyi başaran turizm eğitimi ve araştırmaları, Türkiye'de de benzer gelişim göstermiştir. Özellikle, 1960'lı yıllarda Amerika Birleşik Devletleri, İngiltere, Belçika ve Fransa gibi bazı Batı ülkelerinde yaygınlaşmaya başlayan turizm eğitimi ve araştırmalarının, aynı dönemde Türkiye'de de akademik düzeyde yayılmaya başladığı belirtilmektedir (Kozak 2020a). 1979 yılında Ege Üniversitesi Turizm ve Otel İşletmeciliği Yüksekokulu'nun akademisyenleri tarafından çıkarılan Turizm İşletmeciliği Dergisi'nin, günümüzdeki en saygın uluslararası turizm dergilerinden biri olan Tourism Management dergisi ile hemen hemen aynı dönemde yayın hayatına başlaması (İçöz ve Kozak 1999) bu açıdan anlamlıdır.

Tarihsel gelişimde olduğu gibi, turizm araştırmalarının niceliği açısından da Türkiye gelişmiş ülkelerden geri kalmamıştır. Hatta turizm araştırmalarının niceliği bakımından Türkiye, dünyada ilk 10 ülke arasında yer almaktadır (Park vd. 2011). Diğer yandan, ne yazık ki, yapılan birkaç güncel araştırmada, Türkiye'nin aynı zamanda şaibeli yayıncılık konusunda da ön sıralarda yer aldığı görülmektedir (Kurt 2018; Demir 2018; Alrawadieh 2020). Bu durum, Türkiye merkezli yazarların yayınlarının incelenmesini gerektirdiği kadar, Türkiye merkezli dergilerin özelliklerinin de araştırılmasını gerekli kılmaktadır. Ayrıca, dünyanın birçok ülkesinde olduğu gibi, Türkiye'de de son yıllarda yayın yapma isteği ve/ veya ihtiyacı çeşitli nedenlerden (örn. doçentlik, akademik yükselme ve atama ölçütleri, teşvik ödenekleri) dolayı artmıştır. Bunun yanı sıra, internetin sağladığı imkânlar ve bilimsel kuruluşların sunduğu kolaylıklar sayesinde (örn. DergiPark Platformu), yeni çıkan dergilerin sayısı da kayda değer biçimde artmıştır.

İlk bakışta bu durum, araştırmacıların yaptıkları çalışmaları yayınlamak için daha geniş olanaklar sağlıyor olsa da; kalite ve bilimsel bütünlük bakımından bazı endişeler uyandırabilmektedir. Endişenin ana kaynağı; bu ani artışın toplumsal sorunlara çözüm üretme ve bilimsel yazına katkı sağlama konusundaki istek ve arzu değil; arz-talep işleyişine bağlı olabilme ihtimalinden kaynaklanmaktadır. Türkiye'nin Beall yağmacı dergiler listesinde Hindistan'dan sonra ikinci s1rada yer alması (Akça ve Akbulut 2018), bu endişenin ne kadar haklı olduğunun bir göstergesidir. Buradan hareketle çalışma, Türkiye merkezli turizm ve otelcilik alanındaki dergilerin mevcut durumunu farklı açılardan değerlendirerek ele almaktadır. Bu çalışma, bilimsel sorumluluk çerçevesinde böyle bir görevi üstlenerek Türkiye'de sosyal bilimler ve özellikle turizm araştırmalarının kalitesine ilişkin artan kaygılara yanıt vermeye (Akça ve Akbulut 2018; Demir 2018; Kocak 2019; Alrawadieh 2020) ve bu açıdan turizm akademik dergilerinin ana sorunlarına değinmeye çalışmaktadır.

\section{DÜNYADA TURIZM VE OTELCILIK ALANINDA HAKEMLI DERGILER}

Psikoloji ve sosyoloji gibi sosyal bilimlerin bazı dallarından farklı olarak, turizm ve otelcilik ala$\mathrm{n} 1$ nispeten yeni bir disiplin olarak değerlendirilmekte, olgunlaşıp olgunlaşmadığı konusunda ise akademik tartışmalar hâlâ devam etmektedir (de Esteban vd. 2015; Kozak ve Kozak 2016; Tribe ve Liburd 2016; Tasci 2019). Turizmin disiplinler arası doğası gereği, turizmle ilgili yapılan ilk bilimsel çalışmalar; ekonomi, coğrafya ve sosyoloji gibi farklı disiplinlerin araştırmacılarının turizme yönelmeleriyle ortaya çıkmıştır (Kozak ve Kozak 2016). Akademik yayıncllık bakımından ise, sistematik ve bağımsız olarak turizm araştırmaları ilk defa 1946 yılında The Tourist's Review (şu anki adıyla Tourism Review) adlı dergide yayınlanmaya başlamıştır. 1960 yılı itibariyle turizm alanında sadece dört dergi var iken, izleyen 20 yıl içinde bu sayı 11'e ulaşmıştır (McKercher 2020). Günümüzde ise, ağırlıklı olarak İngilizce veya İngilizcenin yanı sıra başka bir dilde turizm ve ağırlama odaklı yayın yapan uluslararası dergilerin sayısı 400'ü aşmaktadır (McKercher 2020). Kozak'a (2020b) göre, turizm dergilerinin gelişimi üç ana aşamadan geçmiştir. Bu aşamalar şu şekilde özetlenebilir:

- 1940-1980'li yıllar arasında Annals of Tourism Research gibi ilk (ve bugüne kadar en saygin) turizm dergilerinin ortaya çıktığı dönem, 
- 1990-2000'li yıllar arasında Journal of Sustainable Tourism gibi turizm içerisinde belirli temalara yönelik dergilerin ortaya çıtı̆̆g dönem,

- Son olarak, 2010-2020'li yıllar arasında turizm dergilerinin nicelik ve nitelik açısından çeşitlenmiş hale gelmesi ve Taylor and Francis ve Elsevier gibi uluslararası dev yayınevlerinin çatısı altında faaliyet gösterdiği dönemdir.

Yayıncllık bakımından, genel itibariyle, bilimsel dergiler; bağımsız yayınevleri, üniversiteler, dernek ve vakıflar veya devlet destekli araştırma merkezleri tarafından yayımlanmaktadır. Buna bağlı olarak, akademik dergicilikten doğan maliyet; yazarlar, okuyucular, devlet kuruluşları, özel kuruluşlar veya dergiye yapılan bağışlarla karşılanmaktadır (Asan ve Kıran 2019). Bilimsel çıktıların toplumun refahını arttırmayı amaçladığı varsayılarak; maliyetin, akademik yayıncılığın en önemli iki tarafı olan yazar ve/veya okuyucuya yüklenmesi, sorgulanması gereken bir husustur. $\mathrm{Bu}$ anlamda, bağımsız ticari yayınevleri kadar, açık erişim politikasını benimseyip maliyeti yazarlara yükleyen dergilerin masumiyeti de tartışlabilir.

Üç asırdan fazla süredir varlığını devam ettiren bilimsel dergiler (Ertaş ve Kozak 2020), son yıllarda küreselleşen dünyanın yeni işleyişleri ve internetin meydana getirdiği gelişmeler sayesinde birtakım değişikliklere uğramıştır. $\mathrm{Bu}$ gelişmelerin başında, dergilerin sanal ortamda yaygınlaşması gelmektedir. Bu anlamda tüm disiplinlerde açık erişimli dergilerin sayısında ciddi bir artış gözlemlenmektedir (Kozak ve Hartley 2013). Ne var ki, bu açık erişim modeli; günden güne sayısı artan ve yasal ve etik olmayan bir şekilde yazarlardan gelir sağlayan yağmacı dergi ve yayınevleri tarafından suistimal edilmektedir (Alrawadieh 2020). Yağmacı dergiler; diğer disiplinlerde olduğu gibi turizm ve otelcilik alanına da nüfuz etmiştir. Nitekim Eylül 2020 yılı itibariyle, bu satırların yazarları Cabells listesinde toplam 45 yağmacı turizm dergisi tespit etmiştir.

\section{TÜRKIYE'DE TURIZM VE OTELCILIK ALANINDA HAKEMLI DERGILER}

Türkiye'de turizm araştırmalarının başlang1cı 1970'li yıllara dayanmaktadır (İçöz ve Kozak
1999). Ancak 1980'li yıllarda önem kazanmaya başlayan turizm; yükseköğretim programlarının yaygınlaşmasıyla beraber, ilgi toplayan bir araştırma konusu olarak kendini göstermeye başlamıştır. Ne var ki, 1979 - 1983 yılları arasında yayınlanan ve kısa bir yayın hayatı olan $\mathrm{Tu}$ rizm işletmeciliği Dergisi dışında turizm odaklı bilimsel dergilerin doğuşu zaman almıştır. Dolayısıyla, turizm ve otelcilik ile ilgili ilk araştırmalar, turizm odaklı olmayan diğer sosyal bilimler dergilerinde yayımlanmaktaydı. Örneğin, 2010 yılına kadar, turizm ile ilgili araştırmaların üçte ikisinden fazlasının turizm dışındaki dergilerde yayımlandığı belirtilmektedir (Evren ve Kozak 2014). Daha sonra detaylı olarak görüleceği üzere, 2010 yılına kadar, Türkiye'de sadece altı adet hakemli turizm dergisi bulunmakta iken, 2020 yılı itibariyle bu sayı 43'e ulaşmıştır. Halen varlığın devam ettiren en eski turizm dergisi ise Anatolia: Turizm Araştırmaları Dergisi'dir. Yüksek lisans öğrencisi iken Nazmi Kozak tarafından 1990 yılında başlatılan dergi (Kozak 2014), 1997 yılından bu yana hakemli ulusal bir dergi olarak yayın hayatını sürdürmektedir. Anatolia: Turizm Araştırmaları Dergisi, Türkiye'de turizm alanında önderlik yapmasının yanı sıra (Evren ve Kozak 2014); diğer turizm dergileri arasında da saygın bir konumda bulunmaktadır.

Türkiye'de, akademik düzeyde araştırmaların önem kazanmasının yükseköğretimin getirdiği çeşitli düzenlemelere bağlı olduğu görülmektedir. Tonta'ya (2017) göre, 1990'l1 yılların başlarına kadar makalelerin hakemli dergilerde yayınlanması konusu üniversitelerce pek tartışılmamış, hatta konunun gündeme gelmesi için henüz şartlar olgunlaşmamıştır. Ancak, 1993 yılında başlatılan Uluslararası Bilimsel Yayınları Teşvik (UBYT) Programı ve 2015 yılında yürürlüğe giren akademik teşvik ödeneğinin, nicelik olarak bilimsel araştırmaları arttırdığı görülmektedir. Ancak, akademik yükselme ölçütleri ve teşvik sisteminin birçok yan etkiyi meydana getirdiği belirtilmektedir. Bu anlamda, yayın etiği konusunda birçok güncel araştırmada, Türkiye'de sosyal bilimler (Demir 2018) ve özellikle turizm ve otelcilik (Alrawadieh 2020) araştırmalarıyla ilgili endişe verici bulgulara rastlanmaktadır. Örneğin, Kurt'un (2018) çalışmasında, yağmacı 
yayıncılık bakımından Türkiye'nin ilk dört ülke arasında yer aldığı görülmektedir. Bu durum, Türkiye merkezli araştırmacıların çıtılarının ele alınmasını gerektirdiği kadar, Türkiye merkezli dergilerin hâlihazır durumunun da incelenmesini gerekli kılmaktadır.

\section{HAKEMLI DERGILERDE ÖNDERLIK}

Akademik yayıncılıkta önderlik büyük önem taşımaktadır. Bu konuda, özellikle editör veya sonrasinda editör kurulu belirleyici rol oynamaktadır. Derginin kalitesini, performansını ve bilim camiasındaki itibarın belirleyen kilit unsurlardan biri, o derginin baş editörüdür (Law vd. 2010). Bir derginin baş editörü bilimin bekçisi olarak değerlendirilmekte olup, geçerli ve güvenilir bilimsel çıktıların yayınlanmasından da sorumludur (Alrawadieh ve Zareer 2019). Aynı zamanda, kaliteli hakem bulma ve davet etme, hakemlerden gelen raporları inceleyip karar verme gibi baş editörün hakemlik sürecindeki rolü oldukça önemlidir (Correia ve Kozak 2017). Bilimsel bütünlük kuralları doğrultusunda işleyen dergi editörlügüu, bilimin gelişimini sağlayıp bilimden beklenen katkıları pekiştirirken, doğru yürütülmeyen dergi editörlüğü, bilgi kirliliğine yol açarak bilim camiasına olan güvene ciddi zarar verebilmektedir. Özetle, dergi editörlügünü fahri bir makam olarak değil, toplumun ve bilim camiasının nezdinde sorumluluk gerektiren bir görev olarak değerlendirmek gerekmektedir. Turizm ve ağırlama alanında bu konu, uluslararası alan yazında sınırlı da olsa ele alınmışken (Law vd. 2010), ulusal alan yazında hiçbir araştırmaya rastlanmamaktadır. Akademik önderliğin araştırılması, hakemli dergilerin kalitesinin ve performansının anlaşılmasını sağlamaktadır.

\section{ARAŞTIRMA YÖNTEMI}

Turizm ve otelcilik alanında Türkiye merkezli hakemli dergilerin gelişimi ve mevcut durumunu incelemek için dergilerle ilgili internet üzerinden tanımlayıcı bir araştırma yapılıp, ardından ilgili dergilerin editörlerinin akademik profilleri betimleme yöntemiyle incelenmiştir. Bu amaçla; öncelikle geniş bir yelpazede, Türkiye merkezli hakemli turizm ve otelcilik dergileri tespit edil- miştir. Dergilerin tespit edilmesinde iki ölçüt göz önünde bulundurulmuştur. Birincisi, söz konusu derginin hakemli olmasi; ikincisi ise derginin adında "turizm", "otelcilik", "turist", "turist rehberliği", "seyahat", "rekreasyon" ve "gastronomi" sözcüklerden birinin geçmesidir. Birinci ölçüt, turizm ile ilgili periyodik olarak hakemli olmayan yazılar yayınlayan dergileri değerlendirme dışı bırakırken; ikinci ölçüt, turizm ve otelcilik konuları ile ilgili makale yayınlayan fakat odak noktası turizm olmayan sosyal bilimler dergilerini değerlendirme dışı bırakmıştır. Yukarıdaki ölçütler doğrultusunda, ULAKBİM veri tabanı, Türkiye Turizm Dizini, Türkiye'de üniversitelerin internet sayfaları ve arama motorları gibi çeşitli yöntemlere başvurmak suretiyle toplam 43 dergi tespit edilmiştir (bkz. EK 1). Bağlı olduğu yayınevi İngiltere merkezli olsa da, Anatolia: An International Journal of Tourism and Hospitality Research Türkiye'den çıttı̆ğ, kurucusu ve eş-editörleri başlangıçtan itibaren Türkiye'de olduğundan, bu dergi de çalışma kapsamında ele alınmıştır.

Bu aşamadan sonra, her derginin yayın başlangiç tarihi, yıl içerisinde çıkarttığı sayı, tarandığı indeks(ler), odak noktası, yayın dili veya dilleri, bir sayıda yayımlanan ortalama makale sayısı ve yazarlardan ücret talep edilip edilmediği şeklinde bibliyografik veriler toplanmıştır. Bu veriler, derginin bağımsız internet sayfası ve/veya yer aldığı DergiPark sisteminden edinilmiştir. Dergilerin bir kısminda (16 tanesi) ücret talep edilip edilmediği belirtilmediği için ilgili editörlere e-posta gönderilerek bilgi edinilmeye çalışılmıştır (14 editör geri dönüş sağlamıştır).

Yukarıda da vurgulandı $\breve{g}$ gibi, bir derginin kalitesini, performansını ve bilim camiasındaki itibarın belirleyen kilit unsurlardan biri, o derginin baş editörüdür (Law vd. 2010). Buradan hareketle, tespit edilen dergilerin baş editörlerinin akademik özgeçmişi (doktora eğitimi temel al1narak), akademik unvanları, Web of Science (WoS) ve Scopus indekslerinde taranan dergilerde yaptıkları hakemli makale sayısı, WoS ve Scopus alıntı sayısı ve H-indeksleri not alınmıştır. Bu verilere ulaşmak için WoS ve Scopus veri tabanlarına başvurulmuştur. Makale ve alıntı sayısı bir araş- 
tırmacının performansı ve bilime katkısını ölçmek için en sık kullanılan ölçütler arasında görülmektedir (McKercher 2008; Park vd. 2011). Bu süreç kapsamında sadece hakemli makaleler değerlendirilmiş olup; kitap bölümü, editöryel yazı ve kitap eleştirisi gibi yayınlar değerlendirme d1şı bırakılmıştır. Çalışma kapsamında sadece baş editör(ler) ele alınmış olup, yardımcı editör(ler) ve yönetici editör(ler) değerlendirmeye dâhil edilmemiştir. Son olarak, her editörün turizm ve ağırlama alanında öncülük yapan ilk 10 uluslararası dergide yayını olup olmadığ 1 da araştııılmiştır. Bu dergiler, Tourism Management, International Journal of Contemporary Hospitality Management, Journal of Travel Research, Annals of Tourism Research, Journal of Sustainable Tourism, Journal of Hospitality \& Tourism Research, Cornell Hospitality Quarterly, International Journal of Hospitality Management, Journal of Travel \& Tourism Marketing ve Current Issues in Tourism şeklinde belirlenmiştir (Koseoglu 2018).

Şüphesiz akademik performansın ölçülmesinde en önemli kısıtlardan biri, nesnel ölçütlerin kullanılmasının güç olmasıdır (Law vd. 2010). $\mathrm{Bu}$ anlamda, editörler ile ilgili toplanan bu veriler her ne kadar dünyada ve Türkiye'de önemli ölçütler olarak benimsenmiş olsa da, genel itibariyle bir araştırmacının akademik performansını ölçmek için yetersiz ve hatta yanıltıcı olabilmektedir (Adler ve Harzing 2009; Yüksel 2019). Diğer yandan, bir araştırmacı uluslararası alan yazına kayda değer bir katkı sağlamadığı halde, ulusal alan yazına ciddi katkı sağlamış olabilir. Ancak bilimin evrenselliği göz önüne alınırsa, bu durum editörler için geçerli olmayabilir. Bu çalışma kapsamında ele alınan dergilerin önemli bir kısmının uluslararası sıfatını kullanmaları dolayısı ile bir derginin editörünün yaptığı yayınlar ile uluslararası akademik camiada da söz sahibi olması beklenmektedir. Özellikle, dergiye gönderilen makale sayısı ve bunların kalitesi, hakem bulma ve davet etme konularında, editörün tanınırlığı ve itibarının oldukça etkili olduğu bilinmektedir.

Editörler ile ilgili verileri toplarken, bazı editörlerin şaibeli/yağmacı dergilerde makale yayımladıkları belirlenmiştir. Dolayısıyla, başlangıçta çalışma kapsamı dışında tutulmuş olsa da, daha sonra yağmacı dergi ve yayınevlerini içeren Beall listesi ve Cabells yağmacı raporlarına başvurarak söz konusu editörün bu listelerde yer alan dergilerde yayını olup olmadığı araştırılmıştır. Baz1 eleştirilere rağmen (da Silva ve Tsigaris 2018), Beall listesi ve daha güncel olan Cabells yağmacı raporları, daha önceki çalışmalarda da geniş bir şekilde kullanılmıştır (Demir 2018; Strinzel vd. 2019; Alrawadieh 2020). Örneğin; Hindistan merkezli Sryahwa Publications'e bağlı olan Journal of Travel, Tourism and Recreation adlı dergide makale yayımlamış olan bir araştırmacının yağmacı dergide yayını olduğu varsayılmaktadır. Zira bu dergi ve bağlı olduğu yayınevi Beall ve Cabells listelerinde yer almaktadır. Göz ardı edilemeyecek kadar fazla olduğu tespit edilen bu durumu çalışmaya sonradan dâhil etmenin amacı, farkındalık yaratmak ve gelişimi/iyileşmeyi teşvik etmektir. Son olarak, yukarıda belirtilen veri toplama süreci 12 Aralık 2020 tarihinde başlamış ve 21 Aralık 2020 tarihinde tamamlanmıştır.

\section{BULGULAR VE TARTIŞMA}

\section{Dergilere İlişkin Bulgular}

Hâlihazırda faaliyette olmayan dergiler değerlendirme dışında bırakıldığında, Türkiye merkezli ilk hakemli turizm dergisi 1990 yılında yayınlanmaya başlayan ve 1997 yılından bu yana hakemli dergi olarak faaliyetlerini sürdüren Anatolia: Turizm Araştırmaları Dergisi'dir. Ulusal turizm alan yazınına öncülük eden bu derginin (Evren ve Kozak 2014), 1997 yilında da ilk uluslararası sayıs1 Anatolia: An International Journal of Tourism and Hospitality Research adlı dergide yayınlanmıştır. Halen bu iki dergi ulusal ve uluslararası bağımsız iki ayrı dergi olarak faaliyetlerine devam etmektedir.

2015 yılından öncesine kadar, Türkiye'de 11 turizm dergisi bulunmakta iken, 2020 yılı itibariyle bu sayının yaklaşık dörde katlandığı görülmektedir. Bir alandaki dergilerin çoğalması, o alanın olgunlaşmasını işaret edebilmektedir (Cheng vd. 2011). Ancak, hâlihazırda mevcut olan turizm ve otelcilik dergilerinin çoğunun (yüzde 74) akademik teşvik ödeneği yönetmeliğinin yayınlandı- 
Tablo 1. Dergilerin Bibliyografik Bilgileri

\begin{tabular}{|c|c|c|}
\hline Başlangıç yılı & Sayı & $\%$ \\
\hline $1990-2004$ & 5 & 11,6 \\
\hline $2005-2015$ & 9 & 20,9 \\
\hline 2016 ve sonrası & 29 & 67,5 \\
\hline Toplam & 43 & 100 \\
\hline Odak noktası* & Sayı & $\%$ \\
\hline Turizm, seyahat, rekreasyon & 31 & 72,1 \\
\hline Ağırlama, otelcilik & 5 & 11,6 \\
\hline Gastronomi & 5 & 11,6 \\
\hline Turist rehberliği & 2 & 4,7 \\
\hline Toplam & 43 & 100 \\
\hline Yayın Dili & Sayı & $\%$ \\
\hline Sadece Türkçe & 5 & 11,6 \\
\hline Sadece İngilizce & 6 & 14,0 \\
\hline Türkçe ve İngilizce & 30 & 69,7 \\
\hline İki dilden fazla & 2 & 4,7 \\
\hline Toplam & 43 & 100 \\
\hline Yazar(lar)'dan ücret talep etme durumu & Sayı & $\%$ \\
\hline Ücret söz konusu değildir & 36 & 83,7 \\
\hline Ücret söz konusudur & 5 & 11,6 \\
\hline Belirtilmemekte & 2 & 4,7 \\
\hline Toplam & 43 & 100 \\
\hline
\end{tabular}

*Bu sinıflandirma derginin ismi ve internet sayfasında yer alan "hakkında" kısmı temel alınarak yazarlar tarafından yapilmıştır.

ğ 2015 yılı ve sonrasında ortaya çıkması dikkat çekmektedir (Bkz. Tablo 1). Bu ani artışın altında yatan nedenler kesin olarak bilinmemekle beraber, uluslararası dergide makale yayını için artan talebin etkisi göz ardı edilemez. Dergilerin büyük kısmının (yüzde 79) yılda iki sayı yayınladığı görülmektedir. Dergilerin iki tanesinin WoS veri tabanında ve Scopus indeksinde, altı tanesinin ise Ulakbim veri tabanında tarandığ $\breve{1}_{\text {tespit }}$ edilmiştir. Ancak, dergilerin iki tanesinin Cabells yağmacı raporunda, bir tanesinin ise Beall listesinde yer aldığı tespit edilmiştir. Daha şeffaf olan Cabells yağmacı raporunda yer alan iki derginin bir tanesinde yedi; diğerinde ise sekiz adet ihlalin olduğu gösterilmektedir. Beall listesinde yer alan derginin ise, niçin bu listede yer aldığı anlaşılmamaktadır.
Yayın dili bakımından, dergilerin büyük bir kısmının (yaklaşık yüzde 70) Türkçe ve İngilizce olmak üzere iki dilde makale kabul ettiği görülmektedir ${ }^{1}$. Ne var ki, bu dergilerin son dört sayılarında yayımlanan toplam 1136 makaleden sadece 171'inin (yüzde 15) İngilizce olarak yayınlandığı görülmektedir. İngilizce olarak yayımlanan bu makaleler incelendiğinde ise, yazarların büyük çoğunluğunun (yüzde 81,2) Türkiye adresli olduğu ortaya çıkmıştır. Bir derginin İngilizce makale kabul etmesi, o derginin "uluslararas1" vasfa sahip olduğu anlamına gelmemektedir, zira bir derginin uluslararası olup olmadığı, yazar ve okuyucu dağılımlarının çok uluslu olmasina (Tonta 2017) ve o bilim dalında dünyada en çok kabul gören dilde yayın yapmasına bağlıdır (Kozak 2017). Bu çalışma kapsamında ele alınan dergilerin bir tanesi Türkçe dışında yedi dilde makale kabul ederken, bir başkası ise Türkçe dilinin yanı sıra "diğer diller" de makale kabul ettiğini ifade etmektedir. Bu uygulamanın gerçekçi olmadığ incelendiğinde anlaşılmaktadır. Nitekim söz konusu editör kurulları üyelerinin çeşitli dillerde (özellikle Türkçe ve İngilizce dışındaki diller) gelen makaleleri inceleyip hakem sürecini yürütecek yetkinlikte olup/olmadığ dil üzerinde yoğunlaşmanın; derginin gelişimi, okuyucu kitlesi ve performansı için daha yararlı olabileceği düşünülmektedir. Bu anlamda, Türkçe dilinin bilimsel anlamda güçlendirilmesi için ulusal ölçekli dergilere de ihtiyaç bulunmaktadır. Ancak bu ihtiyaca karşıllık verilirken kaliteden ve bilimsel bütünlükten taviz verilmemelidir.

Turizm ve otelcilik dergilerinin küçük bir kısmının (yüzde 11,6) hâlihazırda açık erişim politikası kapsamında yazarlardan ücret talep ettiği görülmektedir. Yapılan araştırmaların yayınlanması için yazarlardan ücret talep edilmesi, her ne kadar çok tartışılan bir konu olsa da; bu çalışmada, son dört sayıda yayımlanan makale ortalaması esas alınarak, ücret talep eden dergilerin bir sayıda yayımladığ $\breve{g}_{1}$ ortalama makale sayısının $(\bar{X}=29,1 ; \sigma=22,1$; asgari $=7$; azami $=85)$, ücret-

\footnotetext{
${ }^{1}$ Veri toplama sırasında başlangıç yılı itibariyle yeni olan sekiz adet dergi bir veya iki sayı çıkartmış, iki tanesi ise henüz sayı çıkartmamıştır.
} 
li olmayan dergilerde yayımlanan ortalama makale sayısindan $(\bar{X}=6,7 ; \sigma=2,9$; asgari $=3$; aza$\mathrm{mi}=38$ ) dört kat fazla olması düşündürücüdür. $\mathrm{Bu}$ durum arz-talep işleyişine aykırı niteliktedir. Dergilere bir yılda gelen makale sayısı ve kabul oranını bilmeden bu eğilimi açılamak mümkün değildir. Özetle, ücret talep eden dergilerde yayımlanan makale sayısı endişe verici olabilir. Örneğin, bir dergide sadece bir sayıda 85 makale yayınlandığ le sayısının yüksek olması, o çalışmaların kalitesi noktasında endişe uyandırabilir (Ertaş ve Kozak 2020).

Hemen hemen tüm uluslararası yayınevlerine bağlı olan dergilerde kabul edilen makaleler, çalışmanın yayımlanacağı cilt ve sayı numarası tayin edilmeden önce çevrimiçi olarak yayınlanmaktadır. Böylelikle makalenin okuyuculara daha hızlı ulaşması sağlanmaktadır. Bu uygulamaya Türkiye'de sadece Taylor and Francis tarafindan yayınlanan Anatolia: An International Journal of Tourism and Hospitality Research, İstanbul Üniversitesi tarafından yayımlanan Journal of Tourismology ve Akdeniz Üniversitesi tarafından yayımlanan Advances in Hospitality and Tourism

Tablo 2. Baş Editörlerin Genel Profili

\begin{tabular}{lrr}
\hline Cinsiyet & Sayı & $\%$ \\
\hline Erkek & 54 & 85,7 \\
Kadın & 9 & 14,3 \\
Toplam & 63 & 100,0 \\
\hline Akademik Unvan & Sayı & $\%$ \\
Profesör & 29 & 46,0 \\
Doçent Doktor & 20 & 31,7 \\
Dr. Öğr. Üyesi & 10 & 15,9 \\
Diğerleri & 4 & 6,4 \\
Toplam & 63 & 100,0 \\
\hline Akademik özgeçmiş & Sayı & $\%$ \\
Turizm işletmeciliği & 37 & 58,7 \\
İ̧letme & 14 & 22,3 \\
Diğerleri & 12 & 19,0 \\
Toplam & 63 & 100,0 \\
\hline
\end{tabular}

Research dergilerinde rastlanmaktadır. İncelenen dergilerin üç tanesinin sayfasında "Kabul Edilmiş Makaleler" şeklinde bir kısım eklenmiş olsa da, içindeki makalelerde sadece başlı̆ga ve yazarların isimlerine erişilebilmektedir.

\section{Editörlere İlişkin Bulgular}

Bu çalışmada ele alınan dergiler toplam 63 baş editör tarafından yürütülmektedir. Bu editörlerin genel profili Tablo 2'de gösterilmiştir.

Çalışmanın ana amaçlarından biri, akademik performans açısından Türkiye merkezli turizm dergilerinin editörlerinin genel durumunu ortaya koymaktır. Elde edilen bulgulara göre, baş editör başına düşen WoS makale ortalaması 5,3 $(\sigma=11,2$; asgari $=0$; azami $=78)$, Scopus makale ortalaması ise 6,2 $(\sigma=14,4$; asgari $=0$; azami $=$ 102) olarak görülmektedir. WoS ve Scopus alıntı sayısının ortalaması sirasiyla $72,8(\sigma=301,2$; asgari $=0$; azami $=2359)$ ve $120,3(\sigma=563,1$; asgari $=0$; azami $=4464$ ) olarak tespit edilmiştir. Baş editörlerin WoS ve Scopus H-indekslerinin ortalamasi sirasiyla 2,2 $(\sigma=3,6$; asgari $=0$; azami $=20)$ ve 2,5 $(\sigma=4,6$; asgari $=0$; azami $=30)$ olarak görülmektedir. Anatolia: An International Journal of Tourism and Hospitality Research dergisinin eş-editörü olan Metin Kozak'ın çalışmada kullanılan tüm ölçütlere göre en yüksek akademik performansa sahip olduğu ortaya çıkmıştır. Kozak'ın yukarıda listesi verilen en saygın 10 dergide 32 makale yayınladığı anlaşılmaktadır. Kozak'ın uluslararası turizm araştırmalarında nicelik açısından en verimli (Park vd. 2011) ve alıntı bakımından en etkili (McKercher 2008) araştırmacılar arasında yer alması göz önünde bulundurulduğunda; bu sonuç şaşırtıcı değildir. Ne var ki; büyük tabloya bakıldığında, editörlerin büyük kısmının, uluslararası turizm camiasındaki bilimsel katkılarının oldukça sinırlı olduğu görülmektedir. Tablo 3'te gösterildiği gibi, editörlerin üçte birinin Türkiye'deki bilimsel kuruluşlar gibi uluslararası bilimsel kuruluşlarca muteber olarak kabul edilen WoS ve Scopus indeksli dergilerde hiç yayını olmadığ 1 ortaya çıkmıştır. Benzer şekilde, WoS ve Scopus alıntı sayısı bir etki göstergesi olarak kabul edilirse, editörlerin önemli bir kısmının (yüzde 43-46 arası) uluslararası alan yazında hiçbir 
Tablo 3. Baş Editörlerin Akademik Performansı

\begin{tabular}{|c|c|c|c|c|c|}
\hline WoS makale sayısı & Sayı & $\%$ & Scopus makale sayısı & Sayı & $\%$ \\
\hline Hiç & 20 & 31,7 & Hiç & 21 & 33,3 \\
\hline 1 & 9 & 14,3 & 1 & 13 & 20,6 \\
\hline 2 & 7 & 11,1 & 2 & 5 & 8,0 \\
\hline 3 & 7 & 11,1 & 3 & 7 & 11,1 \\
\hline 4 & 3 & 4,8 & 4 & 2 & 3,2 \\
\hline 5 & 4 & 6,3 & 5 & 1 & 1,6 \\
\hline 6-19 & 8 & 12,7 & 6-19 & 9 & 14,3 \\
\hline 20 ve üzeri & 5 & 8,0 & 20 ve üzeri & 5 & 7,9 \\
\hline WoS alıntı sayısı & Sayı & $\%$ & Scopus alıntı sayısı & Sayı & $\%$ \\
\hline Hiç & 27 & 42,9 & Hiç & 29 & 46,0 \\
\hline $1-5$ & 6 & 9,5 & $1-5$ & 6 & 9,5 \\
\hline $6-19$ & 11 & 17,5 & $6-19$ & 5 & 8,0 \\
\hline $20-99$ & 10 & 15,9 & $20-99$ & 12 & 19,0 \\
\hline 100 ve üzeri & 9 & 14,3 & 100 ve üzeri & 11 & 17,5 \\
\hline WoS H-indeks & Sayı & $\%$ & Scopus H-indeks & Sayı & $\%$ \\
\hline 0 & 27 & 42,9 & 0 & 29 & 46,0 \\
\hline 1 & 12 & 19,0 & 1 & 10 & 15,9 \\
\hline 2 & 8 & 12,7 & 2 & 5 & 8,0 \\
\hline $3-5$ & 7 & 11,1 & $3-5$ & 10 & 15,9 \\
\hline 6 ve üzeri & 9 & 14,3 & 6 ve üzeri & 9 & 14,3 \\
\hline ilk 10 dergide makale sayısı & Sayı & $\%$ & Yağmacı dergilerde makale & Sayı & $\%$ \\
\hline Hiç & 51 & 81,0 & Yok & 38 & 60,3 \\
\hline 1 & 6 & 9,5 & Var & 25 & 39,7 \\
\hline 2 & 2 & 3,2 & & & \\
\hline 3 ve üzeri & 4 & 6,3 & & & \\
\hline
\end{tabular}

etkisinin olmadığı görülmektedir. Editörlerin büyük çoğunluğunun (yüzde 81) turizm ve ağırlama alanında en saygın ilk 10 dergide hiç yayını olmaması da dikkat çekmektedir.
Son olarak, başlıca sorumluluklarından biri bilimsel doğruluğu denetlemekle ve sadece geçerli ve güvenilir bilimsel çıktıların yayınlanmasını sağlamakla mükellef olan editörlerin önemli 
bir kısmının (yaklaşık yüzde 40) şaibeli/yağmacı dergilerde en az bir yayını olduğu ortaya çıkmış$\operatorname{tir}(X=0,80 ; \sigma=1,4$; asgari $=0$; azami $=9)$. Hatta Cabells yağmacı raporlarında yer alan ve çalışmada ele alınan dergilerden birinin editörünün dokuz adet makalesini çeşitli yağmacı dergilerde yayımladığı anlaşılmaktadır. Bilinçli ya da bilinçsiz olarak şaibeli/yağmacı dergilerde yayın yapan araştırmacılar, bilimsel camiada yıkıcı ve telafisi mümkün olmayan sonuçlara yol açabileceği gibi (Akça ve Akbulut 2018), bilimsel kuruluşların ve bu kuruluşların bulunduğu ülkenin imajını da olumsuz yönde etkileyebilmektedir (Alrawadieh 2020).

\section{SONUÇ}

$\mathrm{Bu}$ araştırmada bilimsel iletişimin en önemli araçlarından biri olan hakemli dergiler ele alınarak Türkiye merkezli turizm dergilerinin gelişimi ve güncel durumu farklı açılardan değerlendirilmiştir. Elde edilen bulgular bilimsel çalışmaların etkinliği ve sürekliliği açısından her ne kadar endişe verici olsa da, bu çalışma teorik açıdan mevcut alan yazına katkıda bulunmakta; araştırmacılar başta olmak üzere bilim camiasına da uygulamaya yönelik birçok önemli tavsiye sunmaktadır.

Teorik gelişim bakımından, bu çalışma, diğer bilimsel alanlarda olduğu gibi (Demir 2018; Akça ve Akbulut 2018), turizm ve otelcilik alanında da artan kaygıların dayanaksız olmadığını göstermektedir. Çalışma, aynı zamanda, Türkiye merkezli turizm araştırmalarını ele alan sınırlı sayıdaki araştırmaya katkı sağlamaktadır (Evren ve Kozak 2014). Mevcut araştırmaların çoğu yayınlanan makalelere odaklanmışken, hâlihazır çalışma hakemli dergileri ve bu dergilerin baş editörlerini ele almıştır. Ayrıca, uluslararası alan yazında turizm ve otelcilik dergilerinin gelişimi, kalitesi ve performansı ile ilgili birçok araştırma yapılmış iken (Law vd. 2010; Cheng vd. 2011; Gursoy ve Sandstrom 2016; Koseoglu 2018), ulusal alan yazında çok sınırlı bilgi bulunmaktadır. Bu anlamda, çalışma özellikle Türkiye merkezli dergilerde yayın yapmak isteyen genç araştırmacılar için rehber niteliğindedir.
Bulgulardan yola çıkarak, uygulamaya yönelik önemli önerilerde de bulunulabilir. Öncelikle, araştırmacıların yaptıkları araştırmaları yayımlamak için hangi dergiyi hedefleyecekleri konusunda kapsamlı bir inceleme yapmaları tavsiye edilmektedir. Bu inceleme özellikle dergide yayınlanan makalelerin kalitesi ve derginin baş editörünün bilime olan katkılarına odaklanmalıdır. Bilimsel iletişimde açık erişim politikasının maliyetinin yazarlara yüklenmesi "öde ve yayınlat" kültürünü teşvik etmektedir. Dolayısıyla, ücret talep eden dergiler, araştırmacıların ilk tercihi olmamalıdır.

Elde edilen bulgular, baş editörlerin önemli bir kısmının şaibeli/yağmacı dergilerde yayını bulunduğunu göstermektedir. Söz konusu baş editörlerin niçin bu dergilerde yayın yaptıkları bilinmemekle beraber bu editörler, ilgili yayınları geri çekerek zedelenen itibarlarını düzeltebilirler. Bu çalışmalar var oldukça, bilimsel alan yazın kirlenmeye devam edeceği gibi, araştırmacının itibarına, bağlı olduğu kurumun itibarına ve nihayetinde Türkiye'nin imajına da zarar vermeye devam edecektir. Dolayısıyla, bu itibar düzeltme çabası editörler ve kurumlar açısından önemli bir görev olarak algılanmalıdır. Ayrıca, yükseköğretim kurumlarının ve üniversitelerin, yağmacı dergilerin belirlenmesine, duyurulmasına ve bu alanda uygulanacak yaptırımlara yönelik daha fazla çaba sarf etmeleri gerekmektedir. Örneğin; her alanda şaibeli dergilerin listeleri hazırlanabilir ve bu listeler ile araştırmacılar uyarılabilir. Teşvik ödenekleri yoluyla şaibeli dergilerde yayın yapan araştırmacıları ödüllendirmenin, yağmacı yayıncılığı desteklediği ortadadır.

Son olarak, bu çalışmanın önemli kısıtları söz konusudur. Öncelikle, editörler ile ilgili ele alınan veriler her ne kadar birçok uluslararası kuruluş tarafından kullanılan ölçütler olsa da, bir araştırmacının kalitesini tamamen ölçtüğü söylenemez. Aynı şekilde, bazı dergiler de amaçları gereği sınırlı konularda makale kabul edip, sadece ulusal yazına odaklanmayı seçmiş olabilir. Bu durum, bu dergilerin atıf performansinı etkileyebilir. Gelecekte yapılacak araştırmalarda turizm araştırmacılarınca algılanan dergilerin itibarı, dergilerin endüstride tanınırlığı ve söz konusu 
dergilerde yayınlanan makalelerin turizm eğitiminde kullanılıp kullanılmadığı gibi farklı ölçütler de temel alınabilir. Dergilerde yer alan makalelere yapılan alıntı sayısı de önemli bir gösterge olarak kullanılabilir. Düşük alıntı, bir araştırmanın okunmaya ve atıf vermeye değer olmadığını gösterebilir. Düşük atıf sayısı, aynı zamanda bir ülkenin dünyadaki temsil oranını da azaltmaktadır. Bu konuların gelecekteki çalışmaları teşvik edebileceği düşünülmektedir.

\section{KAYNAKÇA}

Adler, N. J. ve Harzing, A. W. (2009). When Knowledge Wins: Transcending the Sense and Nonsense of Academic Rankings, Academy of Management Learning \& Education, 8 (1): 72-95.

Akça, S., ve Akbulut, M. (2018). Türkiye'deki Yağmacı Dergiler: Beall Listesi Üzerine Bir Araştırma, Bilgi Dünyası, 19 (2): 255-274.

Alrawadieh, Z. (2020). Publishing in Predatory Tourism and Hospitality Journals: Mapping The Academic Market and Identifying Response Strategies, Tourism and Hospitality Research, 20 (1): 72-81.

Alrawadieh, Z. ve Zareer, A. (2019). Exploring Retraction in Tourism and Hospitality Journals, European Journal of Tourism Research, 22: 20-30.

Asan, A., ve Kıran, K. (2019). Yırtıcı-Yağmacı Dergiler ve Açık Erişim Bilimsel Dergilerin Ücret Talepleri Hakkında, Acta Medica Alanya, 3 (2): 201-202.

Cheng, C. K., Li, X. R., Petrick, J. F. ve O'Leary, J. T. (2011). An Examination of Tourism Journal Development, Tourism Management, 32 (1): 53-61.

Correia, A. ve Kozak, M. (2017). The Review Process in Tourism Academia: An Elaboration of Reviewers' Extrinsic and Intrinsic Motivations, Journal of Hospitality and Tourism Management, 32: 1-11.

da Silva, J. A. T. ve Tsigaris, P. (2018). What Value Do Journal Whitelists and Blacklists Have in Academia?, The Journal of Academic Librarianship, 44 (6): 781-792.

de Esteban J, Cetin G. ve Antonovica, A. (2015) Theory of Knowledge of Tourism: A Sociological and Epistemological Reflection, Journal of Tourismology, 1 (1): 2-15.

Demir, S. B. (2018). Predatory Journals: Who Publishes in Them and Why?, Journal of Informetrics, 12 (4): 12961311.

Ertaş, M. ve Kozak, M. (2020). Publish or Perish: The Proportion of Articles Versus Additional Sections in Tourism and Hospitality Journals, Journal of Hospitality and Tourism Management, 43, 149-156.

Evren, S. ve Kozak, N. (2014). Bibliometric Analysis of Tourism And Hospitality Related Articles Published in Turkey, Anatolia: An International Journal of Tourism and Hospitality Research, 25 (1): 61-80.
Gursoy, D. ve Sandstrom, J. K. (2016). An Updated Ranking of Hospitality and Tourism Journals, Journal of Hospitality \& Tourism Research, 40 (1): 3-18.

İçöz, O. ve Kozak, N. (1999). Turizm İşletmeciliği Dergisi'nin Turizm Literatürüne Katkısı Hakkında Bir İnceleme, Anatolia: Turizm Araştırmaları Dergisi, 10 (2): 9-17.

Kocak, Z. (2019). Predatory publishing and Turkey, Balkan Medical Journal, 36 (4): 199-201.

Koseoglu, M. A. (2018). A New Approach to Journal Ranking: Social Structure in Hospitality and Tourism Journals, International Journal of Contemporary Hospitality Management, 32 (2): 389-424.

Kozak, M. (2017). Bilimsel Araştırma: Tasarım, Yazım ve Yayım Teknikleri. Ankara: Detay Yayıncılık.

Kozak, M. (2020a). Turizm Araştırmalarının İslam Coğrafyasındaki Gelişimi ve Jafar Jafari Örneği, Anatolia: Turizm Araştırmaları Dergisi, 31(3): 314-318.

Kozak, M. (2020b). Historical Development of Tourism Journals-A Milestone in 75 Years: A Perspective Article, Tourism Review, 75 (1): 8-11.

Kozak, M. ve Hartley, J. (2013). Publication Fees for Open Access Journals: Different Disciplines-Different Methods, Journal of the American Society for Information Science and Technology, 64 (12): 2591-2594.

Kozak, M. ve Kozak, N. (2016). Institutionalisation of Tourism Research And Education: From The Early 1900s to 2000s, Journal of Tourism History, 8 (3): 275-299.

Kozak, N. (2014). Anatolia: Turizm Araştırmaları Dergisi: 25 Yılın Öyküsü; Bir Dergiden Öte, Belki de Bir Enstitü...., Anatolia: Turizm Araştırmaları Dergisi, 25 (1): 7-25.

Kurt, S. (2018). Why Do Authors Publish in Predatory Journals?, Learned Publishing, 31(2): 141-147.

Law, R., Leung, R. ve Buhalis, D. (2010). An Analysis of Academic Leadership in Hospitality and Tourism Journals, Journal of Hospitality \& Tourism Research, 34 (4): 455-477.

McKercher, B. (2008). A Citation Analysis of Tourism Scholars, Tourism Management, 29 (6): 1226-1232.

McKercher, B. (2020). The Future of Tourism Journals: A Perspective Article, Tourism Review, 75 (1): 12-15.

Mckercher, B., Law, R. ve Lam, T. (2006). Rating Tourism and Hospitality Journals, Tourism Management, 27 (6): 12351252.

Park, K., Phillips, W. J., Canter, D. D. ve Abbott, J. (2011). Hospitality and Tourism Research Rankings by Author, University, and Country Using Six Major Journals: The First Decade of The New Millennium, Journal of Hospitality \& Tourism Research, 35 (3): 381-416.

Strinzel, M., Severin, A., Milzow, K. ve Egger, M. (2019). Blacklists and Whitelists To Tackle Predatory Publishing: A Cross-Sectional Comparison and Thematic Analysis, MBio, 10 (3): e00411-19, 1-16. 
Tasci, A. D. (2019). Holistic Theory development in Tourism and Hospitality: A Perspective Article, Tourism Review, 75 (1): 37-40.

Tonta, Y. (2017). Türkiye'de Yayımlanan ve Web of Science'ta Dizinlenen Dergilerle İlgili Bir Değerlendirme, Türk Kütüphaneciliği, 31(4): 449-482.
Tribe, J. ve Liburd, J. J. (2016). The Tourism Knowledge System, Annals of Tourism Research, 57: 44-61.

Yüksel, A. (2019). Turizm Akademisinde Yanılsamalar, Seyahat ve Otel Işletmeciliği Dergisi, 16 (2): 340-351.

Ek 1. Türkiye Merkezli Hakemli Turizm Dergileri

\begin{tabular}{|c|c|}
\hline Derginin Başlığı & Başlangıç yılı \\
\hline 1. Anatolia: Turizm Araştırmaları Dergisi & 1990 \\
\hline 2. Anatolia: Journal of Tourism and Hospitality Research & 1997 \\
\hline 3. Ankara Hacı Bayram Veli Üniversitesi Turizm Fakültesi Dergisi & 1998 \\
\hline 4. Seyahat ve Turizm Araştırmaları Dergisi & 2004 \\
\hline 5. Seyahat ve Otel İşletmeciliği Dergisi & 2004 \\
\hline 6. Journal of Humanities and Tourism Research & 2010 \\
\hline 7. Turizm ve Araştırma Dergisi & 2012 \\
\hline 8. Journal of Tourism and Gastronomy Studies & 2013 \\
\hline 9. Advances in Hospitality and Tourism Research & 2013 \\
\hline 10. Turizm Akademik Dergisi & 2014 \\
\hline 11. Journal of Recreation and Tourism Research & 2014 \\
\hline 12. Journal of Tourism Theory and Research & 2015 \\
\hline 13. Journal of Tourismology & 2015 \\
\hline 14. Uluslararası Türk Dünyası Turizm Araşı̧ımaları Dergisi & 2015 \\
\hline 15. Güncel Turizm Araştırmaları Dergisi & 2016 \\
\hline 16. Uluslararası Güncel Turizm Araştırmaları Dergisi & 2016 \\
\hline 17. Journal of Multidisciplinary Academic Tourism & 2016 \\
\hline 18. Çatalhöyük - Uluslararası Turizm ve Sosyal Araştırmalar Dergisi & 2016 \\
\hline 19. Journal of Tourism and Management Research & 2016 \\
\hline 20. Türk Turizm Araştırmaları Dergisi & 2017 \\
\hline 21. Uluslararası Global Turizm Araştırmaları Dergisi & 2017 \\
\hline 22. Uluslararası Turizm, Ekonomi ve İşletme Bilimleri Dergisi & 2017 \\
\hline 23. Uluslararası Kırsal Turizm ve Kalkınma Dergisi & 2017 \\
\hline 24. Gastroia: Journal of Gastronomy and Travel Research & 2017 \\
\hline 25. Aydın Gastronomy Dergisi & 2017 \\
\hline 26. Journal of Gastronomy Hospitality and Travel & 2018 \\
\hline 27. Sivas Interdisipliner Turizm Araştırmaları Dergisi & 2018 \\
\hline 28. Turist Rehberliği Dergisi & 2018 \\
\hline 29. Safran Kültür ve Turizm Araştırmaları Dergisi & 2018 \\
\hline 30. Journal of Tourism Intelligence and Smartness & 2018 \\
\hline 31. GSI Journals Serie A: Advancements in TourIsm, Recreation and Sports Sciences & 2018 \\
\hline 32. Journal of Tourism, Leisure and Hospitality & 2019 \\
\hline
\end{tabular}


Ek 1. Türkiye Merkezli Hakemli Turizm Dergileri (Devam)

\begin{tabular}{|c|c|}
\hline 33. Tourism and Recreation & 2019 \\
\hline 34. Journal of Hospitality and Tourism Issues & 2019 \\
\hline 35. Turizm Ekonomi ve İşletme Araştırmaları Dergisi & 2019 \\
\hline 36. Turizm Çalışmaları Dergisi & 2019 \\
\hline 37. Turizm Araştırma Enstitüsü Dergisi & 2020 \\
\hline 38. Journal of Applied Tourism Research & 2020 \\
\hline 39. Avrasya Turizm Araştırmaları Dergisi & 2020 \\
\hline 40. Turist Rehberliği Nitel Araştırmalar Dergisi & 2020 \\
\hline 41. Journal of Global Tourism and Technology Research & 2020 \\
\hline 42. Journal of Global Food Research & 2020 \\
\hline 43. Journal of New Tourism Trends & 2020 \\
\hline
\end{tabular}
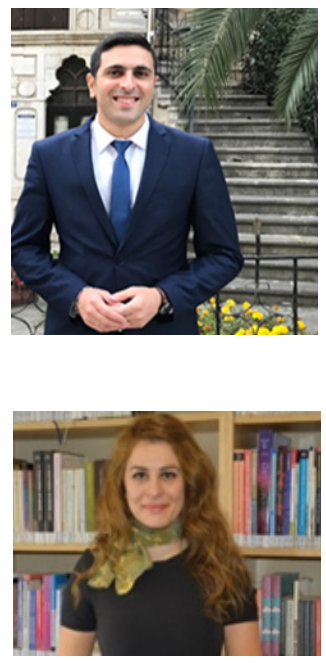

Zaid ALRAWADIEH

Ürdün Üniversitesi Yabancı Diller Fakültesi, İtalyan Dili ve Edebiyatı Bölümü’nden mezun oldu (2009). Yüksek lisans derecesini Pisa Üniversitesi Turizm Işletmeciliği Dalı'ndan (2011), doktora derecesini de İstanbul Üniversitesi Turizm İşletmeciliği Ana Bilim Dalı’ndan aldı (2017). İstanbul Üniversitesi'nde çalışmaya başladı (2018). Doçentlik unvanını turizm alanında aldı (2020). Halen İstanbul Üniversitesi-Cerrahpaşa Sosyal Bilimler Meslek Yüksek Okulu'nda görev yapmaktadır. Temel çalışma alanları turist davranışı ve turizmde paylaşım ekonomisi.

\section{Derya DEMIRDELEN ALRAWADIEH}

Gaziosmanpaşa Üniversitesi Zile Dinçerler Turizm ve Otel İşletmeciliği Yüksekokulu'ndan mezun oldu (2009). Yüksek lisans derecesini Sakarya Üniversitesi Turizm İşletmeciliği Ana Bilim Dalı́ndan (2013) aldı. Doktora derecesini de İstanbul Üniversitesi Turizm İşletmeciliği Anabilim dalından aldı (2021). İstanbul Ayvansaray Üniversitesi'nde çalışmaya başladı (2013). Halen İstanbul Ayvansaray Üniversitesi Plato Meslek Yüksekokulu'nda görev yapmaktadır. Temel çalışma alanları turizmde örgütsel davranış ve turizm eğitimi. 